\title{
Trakya Üniversitesi Tıp Fakültesi Öğrencilerinin Dikey Koridor Derslerine İlişkin Görüşlerinin Değerlendirilmesi
}

\section{The Evaluation Of The Trakya University Faculty Of Medicine Students'Views For The Vertical Corridor Courses}

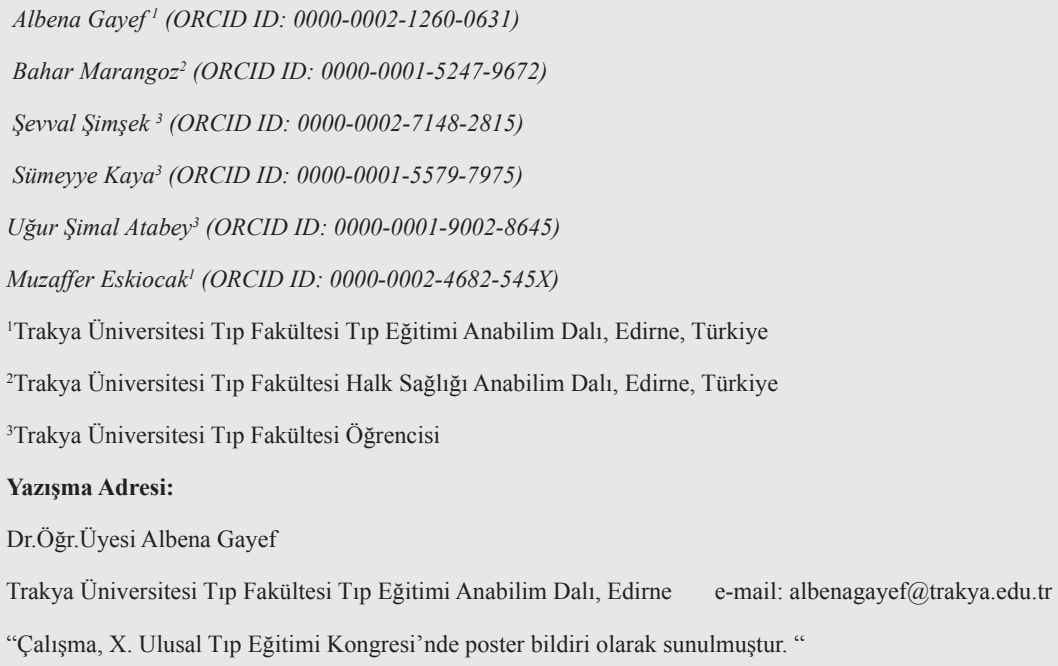

Anahtar Sözcükler:

Tıp Eğitimi, öğrenci, dikey koridor, ders

Keywords:

Medical education, student, vertical corridor, course

Gönderilme Tarihi Submitted:11.02.2019 Kabul Tarihi Accepted: 10.07.2019

\section{ÖZET:}

Giriş ve Amaç: Araştırmanın amacı, tıp fakültesi öğrencilerinin dikey koridor programı kapsamındaki dersler ile ilgili görüşlerini değerlendirmek ve değerlendirmeler sonucunda eğitim programını geliştirmeye yönelik önerilerde bulunmaktır.

Gereç ve Yöntem: Araştırma kesitsel ve tanımlayıcı niteliktedir. Araştırmacılar tarafindan geliştirilmiş olan, sosyodemografik özellikler veöğrencilerin dikey koridor dersleri ile ilgili görüşlerini değerlendirmeye yönelik sorulardan oluşan anket formu Trakya Üniversitesi Tıp Fakültesi ilk beş yılda öğrenim görmekte olan öğrencilere (n=183) 2018 y1lı Mart ayında uygulanmıştır. Ulaşılma oranı $\% 52,2$ 'dir.

Araştırmadan elde edilen veriler, SPSS 24.0 programında analiz edilmiştir. Verilerin analizinde tanımlayıcı istatistikler uygulanmıştır.

Künye: Gayef A, Marangoz B, Eskiocak M, Şimşek Ş, Kaya S, Atabey UŞ. Trakya Üniversitesi Tip Fakültesi Öğrencilerinin Dikey Koridor Derslerine İlişkin Görüşlerinin Değerlendirilmesi. Tip Eğitimi Dünyası. 2019;18(56):95-109 
Bulgular: Öğrencilerin bilim okuryazarl $\breve{g ̆}_{1}$ dersleri ile ilgili "Dersin amaç ve öğrenim hedefleri belirtilmiştir" ifadesine \%39,4'ünün katıldığ $1, \% 37,7$ 'sinin katılmadığı, \%22,4'ünün kararsız olduğu; Hastane gezileri ile ilgili "Gezilerin faydalı olduğunu düşünüyorum." ifadesine öğrencilerin \% 60,2'sinin katıldığ saptanmışır. İnsan Bilimleri, Sosyal Tip, Etik, Girişimcilik Dersleri ile ilgili görüşler değerlendirildiğinde "Bu derslerin iyi hekimlik değerlerini edinmeme katkısı olacağını düşünüyorum." ifadesine öğrencilerin $\%$ 27,9'unun katılmadığı saptanmıştır. Tematik konferanslar ile ilgili olarak "Derslerin Hekimlik mesleğine katkısı olacağını düşünüyorum." ifadesine öğrencilerin \% 33,0'ının katıldı̆̆ saptanmıştır. Sık görülen hastalıklar dersleri ile ilgili görüşler değerlendirildiğinde ise "Derslerin amaç ve öğrenim hedefleri belirtilmiştir." ifadesine öğrencilerin \% 34,9'unun katıldığı saptanmıştır.

Sonuç: Dikey koridor Program1, tıp fakültesi öğrencilerinin geniş bir perspektif bakış açısı ile düşünebilmesini sağlayan, kişisel gelişimine katkıda bulunan ve meslek yaşamına hazırlanmada katkısı olan bir program olarak değerlendirilebilir. Tıp eğitiminde bilim okuryazarlığ 1 , insan bilimleri gibi dikey koridor dersleri ile tıp fakültesi öğrencilerine kazandırılması hedeflenen bilgi ve tutumların geliştirilmesi için bu derslerin amaç ve öğrenim hedefleri daha iyi açıklanmalıdır. Öğrencilerin bu derslere olan ilgisini arttırmaya yönelik olarak mezuniyet öncesi tıp eğitiminde araştırma planlama ve uygulamaların yaygınlaştırılması gerektiği düşünülmektedir.

\section{ABSTRACT:}

Introduction and Aim: The aim of this study is to evaluate the opinions of medical students about the courses within the scope of the vertical corridor program and to make suggestions to improve the education program as a result of the evaluations.

Material and Method: The research is crosssectional and descriptive. The questionnaire, which was developed by the researchers and which consisted of questions about sociodemographic characteristics and the opinions of the students about the vertical corridor courses, was applied to the students studying in the first five years in Trakya University Faculty of Medicine $(n=183)$ in March 2018. Reach rate is 52,2\%. The data obtained from the study were analyzed in SPSS 24.0 program. Descriptive statistics were used to analyze the data.

Findings: Related to science literacy courses $39.4 \%$ of students agreed that "Aim and objectives of the course are specified", 37.7\% did not agrre and $22.4 \%$ were unstable;

- Related to the hospital trips $60.2 \%$ of the students agrred that "I think the trips are useful". When the opinions about Human Sciences, Social Medicine, Ethics and Entrepreneurship Courses were evaluated, it was found that $27.9 \%$ of the students did not agree in the statement.

- "I think these courses will contribute to not obtaining good medical values". 33.0\% of the students agreed in the statement 'I think the lessons will contribute to the profession of medicine" related to thematic conferences. When the opinions about common diseases courses were evaluated, it was found that $34.9 \%$ of the students agreed in the statement "Aim and objectives of the course are specified".

Conclusion: The vertical corridor program can be considered as a program that enables medical students to think with a wide perspective, contribute to their personal development and contribute to the preparation of their career. In the medical education, the aims of the courses and learning objectives should be better explained in order to develop the knowledge of 
the vertical corridor courses such as science literacy, human sciences, and the knowledge and attitudes that are intended to be gained by the medical faculty students. It is thought that research planning and applications should be expanded in pre-medical education in order to increase the interest of students in these courses.

\section{GİISŞ}

Tıp fakültelerinde altı yıllık eğitim sürecinin sonunda sağlıkla ilgili tüm süreçlerde "bütüncül (biyo-psiko-sosyal ve kültürel) yaklaşım” sergileyen, hekimliği insani ve mesleki değerler doğrultusunda kanıta dayalı olarak yapan, bireysel ve mesleki rolleri, sınırları ve sorumluluklarının farkında olarak sürekli mesleki gelişime açık olan hekimlerin yetişmesi amaçlanmaktadır (1). TEPDAD Mezuniyet Öncesi Tıp Eğitimi Ulusal Standartları içerisinde yer alan temel standartlar arasında bir tıp fakültesi eğitim programının içeriği davranış ve sosyal bilimler ile tıpta insan bilimlerine ilişkin uygulamalara yer vermiş, bilimsel ilke ve yöntemleri kullanarak analitik, eleştirel düşünme ve değerlendirme, problem çözme, karar verme gibi becerileri geliştirecek öğrenme fırsatları sağlamış, öğrencilerin bilimsel araştırmalara katılımını özendirecek ve araştırma yapma deneyimi kazandıracak öğrenme firsatları sunmuş olmalıdır. Ayrıca eğitim programı içeriğinde kanıta dayalı tıp uygulamalarına yer verilmiş olması gelişim standartları içerisinde yer almaktadir (2).

Gittikçe artan bilgi yükü tıp eğitiminde yeniden yapılanma çalışmalarını zorunlu hale getirmektedir. T1p eğitiminde ülkemizde de yoğun değişiklikler yaşanmakta, tıp eğitimi bilginin yanısıra klinik beceri ve tutum kazandırma yönündeki uygulamalar ile daha da gelişmektedir. (3). Avrupa Tıp Eğitimi Birliği, artan bilgi yükü ile başa çıkabilmenin yolu olarak, öğretim üyesi merkezli, ezbere dayalı, ayrı ayrı disiplinler halinde, hastanede görülen genellikle komplikasyonlu hastalıklara odaklanmış, standart ve usta-çırak usulü ile beceri kazandırılan bir eğitim modelinden öğrenci merkezli, problem çözmeye yönelik, entegre, topluma dayalı, seçmeli konular ile desteklenmiş ve sistematize beceri kazandırılan bir eğitim modeli”ne geçişi önermektedir (3).

T1p eğitiminde öğrencilere sadece bilgi ya da beceri kazandırmanın çok ötesinde bir kültür, bir yaşam biçimi, bir bakış açısının kazandırılması bir başka deyişle tutum ve davranış geliştirilmesi çok önemlidir. Hekimden tanı koymada bilgili ve uygulamalarda becerikli olmasının yanında hastasinın duygusal gereksinimlerine duyarlı ve yardımcı olması beklenmektedir. Ayrıca hekimlerden beklenen nitelikler içerisinde bilgiye ulaşma yollarını bilmesi, bilimsel bilgiyi kullanabilmesi, bilgiyi üretebilmesi ve paylaşabilmesidir (4).

Tıpta insan bilimleri, insanın sağlık, hastalık, sağlık hizmeti ve hasta-hekim ilişkisi özelinde davranışlarının anlamını irdeleyen çalışmaları içerir. Tibba bu pencerelerden bakabilmek hekimin hastasının dünyasına farklı bir yaklaşım getirmesine katkı sunacaktır. $\mathrm{Bu}$ açıdan bakıldığında davranış ve sosyal bilimlerin tıp eğitimi programındaki yeri ve diğer derslerle olan entegrasyonu önemlidir $(5,6)$.

Tıp eğitiminin akreditasyonu ile ilgili uluslararası ve ulusal kuruluşlar, tıp öğrencilerinde profesyonelliğe ilişkin hedeflerin kazandırılması için tıbbi etik ve beşeri bilimler ile ilgili derslerin müfredatlarda olması gerektğini vurgular (7). Tibbi etik eğitiminin, öğrencilerin ve hekimlerin değerlerini, sosyal bakışlarını geliştirmede, etik ikilemleri ve güç durumları tanımada, başa çıkmada, sorunlarla ilkeli biçimde uğraşabilmede, hekimlik uygulamalarındaki ilişkilerin geliştirilmesinde 
önemli yeri bulunmaktadır (8).

Genel Tip Konseyi (General Medical Council) 1993'teki Yarının Doktorları (Tomorrow's Doctor) raporunda, tıbbi uygulamada ve araştırmada ortaya çıkan etik konuların hassas bir biçimde farkında olunması gerekliliğine dikkat çekmiştir. Ayrıca öğrencinin kendi kişisel değerlerinin belirlenmesi, araştırılması ve sürdürülmesi, öğrencinin kendi klinik pratiğini kavramasına ve somutlaşmış insan doğasının gizeminin tanınmasına dayandırılan bir dizi “öğrenme çıktısı”nı desteklemek üzere tasarlanması gerekliliğini belirtmiştir (9).

Dünyadaki birçok tıp fakültesi; felsefe, etik, edebiyat, tiyatro ve sanat gibi disiplinler aracılığıyla 1950 'le $\neg$ rden itibaren tıp eğitim müfredatına beşeri bilimleri entegre etmiştir (9). Chicago Northwestern Üniversitesi Feinberg Tıp Fakültesi'nde ikinci sınıf öğrencilerine insani ve etik konularda gelişimi sağlamak amacı ile 1978 yılında bir program başlatılmıştır. $\mathrm{Bu}$ programda edebiyat, felsefe, sinema, tarih, antropoloji, hukuk konuları yer almaktadır (10). Tıbbi beşeri bilimler 2000'li yıllardan itibaren Türkiye'deki tıp fakültelerinin eğitim programlarına ya da seçmeli ders olarak müfredatlarına hızla girmeye başlamıştır (9). Hacettepe Üniversitesi Tip Fakültesi'nde "İyi Hekimlik Uygulamaları" programı 2004 yılında başlatılmıştır. Öğrenciler ilk üç yılda "tıp ve sanat", "tıp ve tarih" ve "tıp ve insan" başlıkları ile zorunlu küçük grup çalışmaları yapmakta ve bu çalışmalar sonunda proje üretmekte ve projelerini sözlü sunum ya da poster olarak sunmaktadırlar. Tıbbi beşeri bilimler, hekimlere eleştirel ve yansıtıcı düşünce becerileri, kişilik ve ahlaki gelişim, tıbbi sorun ve küresel olaylar hakkında farklı perspek $\neg$ tif geliştirebilme özelliği kazandırır. Tıbbi beşeri bilimlerin en dikkat çekici özelliği nitelikli hekim yetiştirmede biyopsikososyal modeli esas almasıdır bu da hastayla ilgilenirken tıbbi bilgisini kullanması yanında kendi değerlerini ve hastasının sorunlarını, yaşamını algılayışını değerlendirebilecek duyarlılığa sahip hekim yetişmesini sağlar. Yapılan çalışmalardan ve edinilen deneyimlerden anlaşıldı̆̆ hekimler hastaları ile ilk teması yaşamadan tıbbi beşeri bilimlerle bakış açısını kazanmış olmaları gerekmektedir (9). Ülkemizde Marmara Üniversitesi Tıp Fakültesi eğitim programında da tıbbi beşeri bilimler ile ilgili "Human in Medicine" başlıklı dersler yer almaktadır (11). Trakya Üniversitesi Tıp Fakültesi dikey koridor programı kapsamında bilim okuryazarlığ 1 , insani bilimler ve tıp, sosyal tıp, güncel-gelecekteki tıp, girişimcilik ve yenilikçilik, tematik konferanslar, s1k görülen hastalıklar, hastanemizi ve eğitim araştırma ortamımızı tanıyalım başlıklı hastane gezileri bulunmaktadır. Bilim Okuryazarlığ dersleri arasında örnek olarak "Pubmed ve Ulakbim Kullanımı”; “Orijinal araştırma makalesi tarama ve belirlenen özelliklerde bir örnek makale seçme"; "Araştırma konusunun seçilmesi” başliklı dersler bulunmaktadır. İnsani bilimler ve tıp, sosyal tıp, güncelgelecekteki tıp, girişimcilik ve yenilikçilik derslerine örnek olarak eğitim programımızda “Antropoloji ve Tip”, "Zaman Yönetimi”; “Tip Eğitiminde Hak Temelli Yaklaşım”; "Herkes İçin Sağlık Hedefleri: 1978'den 2030'a” başlıklı dersler yer almaktadir. Tematik konferanslar içerisinde örneğin "Bilim İnsanı Yetkinliği ve T1p Eğitimi”; "Tıp Eğitiminde Kanıta Dayalı T1p Uygulamaları"; "Hasta Hakları"; "Nanoteknoloji ve Tıp”; S1k Görülen Hastalıklar dersleri kapsamında "Sivilce, Uçuk" başlıklı dersler yer almaktadır (12).

Dikey koridor programındaki dersler ile birinci sınıftan itibaren öğrencilerimize etik ve profesyonel değerler, empati, eleştirel düşünme, iletişim becerilerinin kazandırılması, 
mezunlarımızın kanıta dayalı tıp, tıbbi sorunlar ve ilişkili evrensel durumlar hakkında perspektif geliştirmesi, insan sağlığını biyolojik, sosyal ve psikolojik unsurlarıyla bir bütün olarak görmesi, sağlığın geliştirilmesi ve iyileştirilmesi, hastalıkların nedenlerinin belirlenerek hastalıkları önleme yöntemlerini benimsemesi, sağlık hizmetleri ile ilişkili sosyal faktörler ve sağlığın sosyal belirleyicilerini öğrenmesi, neden-sonuç ilişkisi kurarak karar verme, liderlik, araştırma planlama, bilgiye ulaşma yollarını bilmesi, bilimsel bilgiyi kullanabilmesi, bilgiyi üretebilmesi ve paylaşabilmesi hedeflenmiştir.

Eğitim programlarının belirlenmesinde öğrencinin rolü artmakta ve öğrenci geri bildirimlerinin değerlendirilmesi önem kazanmaktadır (3). Değerlendirme öğrenme hedeflerine eğitim öğretim uygulamaları ile ne derecede ulaşılabildiğini saptamayı amaçlar. Öğrencilerin öğrenme ve gelişmelerinin ölçülmesinin yanısıra öğrenme deneyimleri sırasındaki memnuniyetlerini de değerlendirmek öğrenci merkezli eğitimin ana unsurlarından biridir (13). Program değerlendirme süreci içerisinde alınan öğrenci geri bildirimlerinin, biçimlendirici (formative) değerlendirmede eğitim sürecinin bir parçası olarak kullanılması önerilmektedir. Alınan geribildirimler ile öğrencilere eğitimin kalitesini geliştirmeye yönelik sürekli çaba gösterildiğine dair mesaj verilmektedir. Geribildirimlerin öncelikli amacı eğiticilerin öğretim etkinliklerini geliştirmeleri için biçimlendirici (formative) amaçlı bilgi sağlamaktır. Diğer bir amacı da karar verdirici (summative) değerlendirme yapmaya yönelik bilgi sağlamaktır (14).

Araştırmanın amacı, tıp fakültesi öğrencilerinin dikey koridor programı kapsamındaki dersler ile ilgili görüşlerini değerlendirmek ve değerlendirmeler sonucunda eğitim programını geliştirmeye yönelik önerilerde bulunmaktır.

\section{Gereç ve Yöntem}

Araştırma kesitsel ve tanımlayıcı niteliktedir. Veri toplama araçları: Araştırmacılar tarafından geliştirilmiş olan, sosyodemografik özellikler ve ögrencilerin dikey koridor dersleri ile ilgili görüşlerini değerlendirmeye yönelik sorulardan oluşan anket formu, Etik Kurul onayını takiben Trakya Üniversitesi Tip Fakültesi "ilk beş yılda öğrenim görmekte” olan öğrencilere 2018 y1lı Mart ayında uygulanmıştır. Anket formu, bilim okuryazarlığı dersleri, hastane gezileri, insan bilimleri, sosyal tıp, etik ve girişimcilik dersleri, tematik konferanslar ve sık görülen hastalıklar dersleri ile ilgili görüşlerin değerlendirildiği 5'li Likert tipi sorulardan ve her bir ders grubu için olumlu, olumsuz deneyimlerin ve önerilerin sorulduğu 3 açık uçlu sorudan oluşmuştur. Öğrencilerin gönüllü olurları alındıktan sonra anket formları öğrenciler tarafindan doldurulmuştur.

Araştırmanın Evreni ve Örneklemi: Fakültemiz 1,2,3,4,5.sınıf öğrencileri araştırma evrenimizi oluşturmaktadır. Evren büyüklüğü Trakya Üniversitesi Tıp Fakültesi 1,2,3,4 ve 5.sınıf öğrenci mevcutları toplamıdır $(\mathrm{N}=1274)$. Örnekleme alınacak kişi sayısı 334 olarak hesaplanmış, olası sorunlar göz önüne alınarak 350 öğrencinin seçilmesine karar verilmiştir. Evrenden sistematik örnekleme yöntemiyle seçilmiş 350 öğrenciden araştırmaya katılmayı kabul eden 183 öğrenciye anket uygulanmıştır (Ulaşılma oranı \%52,2).

Verilerin Analizi: Araştırmadan elde edilen veriler, SPSS 24.0 paket programında analiz edilmiştir.

İstatistiksel Analiz: Verilerin analizinde tanımlayıcı istatistikler uygulanmıştır.

Etik Kurul Onayı: $\mathrm{Bu}$ araştırma Trakya Üniversitesi Tıp Fakültesi Bilimsel Araştırmalar 
Etik Kurulu tarafindan (Karar no: 05-26, Protokol no: 2018/115) onaylanmıştır.

\section{BULGULAR}

Bilim Okuryazarlığ́1 derslerine ilişkin görüşler değerlendirildiğinde, öğrencilerin "Dersin amaç ve öğrenim hedefleri belirtilmiştir" ifadesine \%39,4'ünün katıldı̆ğ, \%37,7'sinin katılmadı̆̆ 1 , \%22,4'ünün kararsız olduğu saptanmıştır. "Dersin yapılacağı yer belirlidir." ifadesine öğrencilerin \%74,9'unun katıldığ1; öğrencilerin \%78,1'inin "Ders, sorumlu öğretim üyesi tarafindan yürütülmektedir." ifadesine katıldığ1 belirlenmiştir. "Dersin uygulayıcısı öğretim üyesi amaç ve öğrenim hedefleri doğrultusunda motivedir.“ ifadesine öğrencilerin \% 48,6'sının katıldığ1; "Dersler aksatılmaksızın belirlenen gün ve yerde işlenmektedir." ifadesine öğrencilerin \% 59,1'inin katıldığı saptanmıştır. "Ders öncesinde öğrencilerin dersle ilgili beklentileri öğrenilmektedir." ifadesine öğrencilerin \%57,4'ünün katılmadığ1; “Ders programının zaman kurgusu uygun, dersler aras1 süre yeterli." ifadesine öğrencilerin \%41,5'inin katıldığı saptanmıştır. "Dersten sorumlu öğretim üyesiyle birlikte derste öğrendiklerimizi uygulamak amacıyla bir araştırma yapmayı planladık." ifadesine öğrencilerin \%65'inin katılmadığ1; "Dersin faydalı olduğunu, iyi bir hekim olmama katkı sağladığını düşünüyorum." ifadesine öğrencilerin \%48,7'sinin katılmadığı; "Bilim Okuryazarlığı eğitimime aynı hoca ile devam etmek isterim." ifadesine öğrencilerin \%55,7'sinin katıldığg belirlenmiştir (Tablo 1).

Öğrencilerin bilim okuryazarlığı derslerine ilişkin geribildirimleri "Öğrenme süreci”, "Derslerin içeriği”, "Ders Programı” olmak üzere üç tema halinde analiz edilmiştir.

Öğrenciler, bilimsel araştırma basamakları, makale okuma konusunda bilgi sahibi olduklarını, bilimokuryazarlığı derslerinin öğrenme süreci açısından gerekliliğini ve önemini belirtmişlerdir:

"Pubmed benzeri veritabanı kullanımını öğrendim. Bilimsel araştırma basamakları konusunda bilgi sahibi oldum." (1.sınıf öğrencisi)

"Makale okuma konusunda uygulamalı şekilde bilgi sahibi olduk. Hocaların bilgilerinden, deneyimlerinden ve bakış açısından faydalandık." (2.sınıf öğrencisi)

"İyi bir hekim bilim adamı olmak yönlendirilmemiz bilgilendirmemiz güzel

okuldaki hocalarımızın tecrübelerinden faydalanıyoruz." (3.sınıf öğrencisi)

"T1p eğitimi alan bir öğrencinin bu dersi alması ve bu programı nasıl uygulandığını öğrenmesi gerektiğini düşünüyorum. Kariyer ve kendimi geliştirmesi açısından önemli buluyorum." (5.sınıf öğrencisi)

Öğrenciler, derslerin içeriği ve ders programı ile ilgili önerileri olduğunu belirtmişlerdir:

"Dersler çok değişken ve yoğun sadeleştirilmeli. Öğrencinin sıkılmadan dersi takip etmesi için interaktif hale getirilmeli." (2.sınıf öğrencisi)

“Öğrenim hedefleri açıkça belirtilmeli ve bizler sürece aktif olarak katılabilmeliyiz." (2.sınıf öğrencisi)

"Bizler de makale yazımında olmalıyız ve her aşamasını takip etmeliyiz. Etkin bir şekilde makale okumayı öğrenip diğer derslerimize entegre edebilmeliyiz.”(4.sınıf öğrencisi)

"Sunumdan anlattıklarından bazı şeyler aklımda kalmadı. Bir araştırma yapılabilir, uygulama yapılabilirdi.” (1.sınıf öğrencisi)

“Öğretim üyelerimizin de aktif katılıma uygun, yoğun olmayan, öğrenci ile her an iletişimde olabilecek üyelerden seçilmelidir. Birinci sınıftan itibaren yapılmasını, ilk 3 sınıfta aktif olması gerektiğini düşünüyorum.”(5.sınıf öğrencisi)

Öğrenciler, bilimokuryazarlığı derslerinin 
araştırma yapma, planlama, bilimsel makale inceleme açısından motive edici olduğunu belirtmişlerdir:

"Araştırma yapmak, analiz yapmak ve bilimsel makale takip etmek faydalı. Yine bir araştırmanın içinde olmak güven verici ve motive ediyor.” (4.sınıf öğrencisi)

"Dersten sorumlu öğretim üyesi ile derste öğrendiklerimize yönelik bir araştırma yapmaya başladık.” (4.sınıf öğrencisi)

Hastane gezilerine ilişkin görüşler değerlendirildiğinde, "Gezide karşılayan görevlinin faydalı olduğunu düşünüyorum." ifadesine öğrencilerin \% 33,8'inin kararsız olduğu; öğrencilerin \% 63,2’sinin “Gezinin planlandığı anabilim dalının ya da kliniğin yerini bulmakta güçlük çekiyorum." ifadesine katıldığı; "Gezileri çalışan katkısı olmaksızın tamamladım." ifadesine öğrencilerin \% 44,1'inin katılmadığı belirlenmiştir. "Geziler sayesinde hastaneyi tanıdım ve neler yapıldı̆̆ını öğrendim.” ifadesine öğrencilerin \% 63,2'sinin katıldığ1; "Gezilerin faydalı olduğunu düşünüyorum." ifadesine öğrencilerin \% 60,2'sinin katıldığı saptanmıştır (Tablo 2).

Öğrencilerin hastane gezilerine ilişkin geribildirimleri "Öğrenme süreci”, "Derslerin içeriği", "Ders Programı" olmak üzere üç tema halinde analiz edilmiştir.

Öğrenciler, hastane gezilerinin hastaneyi tanıma, hastane bölümlerinin işleyişi hakkında bilgi sahibi olma, hasta- hekim iletişimini izleyebilme açısından önemini belirtmişlerdir: "Hasta-hekim iletişimini yerinde izleyebiliyorum. Hastanemi tanıdım.” (1.sınıf öğrencisi)

"Hastane bölümlerinin işleyişi hakkında bilgi sahibi oluyoruz. Bölümde çalışanlarla iletişim firsatı oluyor.” (2.sınıf öğrencisi)

Öğrencilerin hastane gezileri ile ilgili programın geliştirilmesine yönelik önerileri olmuştur:

"İmkanlar doğrultusunda mümkün mü bilmiyorum fakat gruplar daha az kişili planlanabilir, aynı polikliniğe fazla geliyoruz. Ve değerlendirme formlarının biraz daha amaca yönelik sorular içerebileceğini düşünüyorum." (1.sinıf öğrencisi)

“Gezdiğimiz yerlerde hasta yoğunluğu çok olduğu için hastalar doktorlar ve bizim için de zor oluyor çoğu zaman kendi başımıza bir şeyler öğrenmeye çalışıyoruz, bu konuda oradaki görevli kişilerin nasıl davranması gerektiği ile ilgili bilgilendirilmeleri gerekir."(2.sınıf öğrencisi)

İnsan Bilimleri, Sosyal Tıp, Etik, Girişimcilik derslerine ilişkin görüşler değerlendirildiğinde "Ders konularını çok ilginç buluyorum ve içeriğini merak ediyorum." ifadesine öğrencilerin \% 35,5'inin katılmadığı; “ $\mathrm{Bu}$ derslerin iyi hekimlik değerlerini edinmeme katkısı olacağını düşünüyorum." ifadesine öğrencilerin \% 27,9'unun katılmadığ1 saptanmıştır. "Derslere devam zorunluluğu olduğu için katılıyorum.” ifadesine öğrencilerin \% 56,3'ünün katıldığı; "Derslere tıp derslerine çalışmam gerektiği için katılmıyorum.” ifadesine öğrencilerin \% 35,5'inin katıldığ1; "Dersleri ilgi çekici bulduğum için katılıyorum." ifadesine öğrencilerin \% 37,1'inin katılmadığ 1 ; "Derslere kurul sınavında ilgili soru sorulmadığı için katılmıyorum." ifadesine öğrencilerin \% 39,3'ünün katılmadı̆̆ı; "Kurul sinavinda bu derslerle ilgili soru sorulsaydı derslere katılırdım." ifadesine öğrencilerin \% 42,1'inin katılmadığı belirlenmiştir (Tablo 3).

Öğrencilerin İnsan Bilimleri, Sosyal Tıp, Etik, Girişimcilik derslerine ilişkin geribildirimleri “Öğrenme süreci”, "Derslerin içeriği”, "Ders Programı” olmak üzere üç tema olarak analiz 
edilmiştir.

Öğrenciler, İnsan Bilimleri, Sosyal Tıp, Etik, Girişimcilik derslerinin tıp dışı alanlarda bilgi sahibi olma açısından önemini belirtmişlerdir: "Hekimliğin sadece düz bilgiden oluşmadığını gördüm bilgi harici sosyal konuların önemini kavradım.” (1.sınıf öğrencisi)

"Tıp dışı alanlarda bilgi sahibi olmak güzel." (1.sınıf öğrencisi)

"İyi bir hekim olabilmek için gerekli dersler olduğunu düşünüyorum.” (1.sınıf öğrencisi)

"İleride karşımıza çıkabilecek bilgiler sağlanıyor. Çeşitli (hukuk, tıbbi) alanlarda bilgiler sağlanıyor." (2.sınıf öğrencisi)

"Hekimliğin daha bütüncül olduğunu fark ettim. Mesele sadece sağaltım değil.” (2.sınıf öğrencisi)

"Tıp dışında farklı konular görmemiz iyi bir hekim olmamıza katkı sağlar.” (3.sınıf öğrencisi) "Farklı alanlarda bilgi sahibi olmak faydalı. Değişik alanlar tanıyarak hekimlik hayatında yararlı olacağını düşünüyorum.” (4.sınıf öğrencisi)

"İnsan bilimleri, Sosyal tıp ve etik dikkatimi çekiyor. Bu konular hakkında bilgi edinmek güzel bir şey." (5.sınıf öğrencisi)

Öğrencilerin İnsan Bilimleri, Sosyal Tıp, Etik, Girişimcilik derslerine ilişkin öneriler ile ilgili örnek geribildirimler:

"Bu derslerin tıpla olan ilişiğinin anlatılması. Konuların daha ilgi çekici olması.” (1.sınıf öğrencisi)

"Daha çeşitli konular seçilip ilgi çekilebilir." (1.sinıf öğrencisi)

"Daha verimli ve ilgi çekici konularda ve farklı şekillerde işlenebilir. (Slayt üzerinden değil de başka kaynaklardan)" (2.sınıf öğrencisi)

"Hocalar tarafindan daha interaktif eğitim planlanabilir.” (3.sınıf öğrencisi)

"İnsan bilimleri, sosyal tıp, etik gibi konular hakkında film izletilip üzerine yorum yapılabilir.” (5.sınıf öğrencisi)

Tematik Konferanslar ile ilgili görüşler değerlendirildiğinde, "Konuları çok ilginç buluyorum ve içeriğini merak ediyorum." ifadesine öğrencilerin \% 41,5'inin katılmadı̆̆ 1 ; "Tematik Konferansların amaç ve öğrenim hedefleri belirlidir." ifadesine öğrencilerin \% 30,6'sının katılmadığ1; “Konferansların iyi hekimlik değerlerini edinmeme katkısı olacağını düşünüyorum." ifadesine öğrencilerin \% 29,0'ının katıldığı, \% 33,3'ünün katılmadığ1; "Konferanslara ilgi çekici bulduğum için katılıyorum.” ifadesine öğrencilerin \% 46,4'ünün katılmadığı; "Konferanslara tıp derslerine çalışmam gerektiği için katılmıyorum." ifadesine öğrencilerin \% 42,6'sının katıldığı; "Konferanslara devam zorunluluğu olduğu için katılıyorum." ifadesine öğrencilerin \% 60,1'inin katıldığı saptanmıştır (Tablo 4).

Öğrencilerin tematik konferanslara ilişkin geribildirimleri “Öğrenme süreci”, "Derslerin içeriği" ve "Ders Programı" olmak üzere üç tema olarak analiz edilmiştir.

Örnek geribildirimler:

"Farklı konularda bilgi sahibi olabiliyoruz." (1.sınıf öğrencisi)

"Bazı derslerden ilgi çekici şeyler öğrendim." (2.sınıf öğrencisi)

"İlgimi çeken dersler, konular bizlerin bilgilenmesine yardımcı.” (3.sınıf öğrencisi)

"Kendi bölümümüzden hocaların verdiği derslerden mesleki tecrübe açısından fayda sağladım. (Örneğin Deprem ve Böbrek dersi)" (4.sınıf öğrencisi)

"Sıkıcı teorik ders anlatım biçiminden sıyrılmış, çarpıcı, dikkat çeken anlatım tarzı benimseyen hocalarımdan çok güzel şeyler öğrendim." (5.sinıf öğrencisi)

"Bazı konular ilgimi çekmiyor." (1.sınıf 


\section{öğrencisi)}

"Bu derslerin bizi geliştirdiğine inanmıyorum.

Zaman kaybı olarak görüyorum.” (3.sınıf öğrencisi)

"Tıp fakültesi dışında ders anlatmaya gelen hocaların bizi yeterince anlayıp konuya hangi açıdan yaklaşması gerektiğini bildiğini düşünmüyorum.” (4.sınıf öğrencisi)

Öğrencilerin Tematik Konferansları

Geliştirmeye İlişkin önerileri ile ilgili örnek geribildirimler:

"Devam zorunluluğu olmamalı." (1.sınıf öğrencisi)

"Derslerin süreleri içeriği uygun şekilde kısaltılmalıdır, konular daha deneyimli hocalar tarafından anlatılmalıdır.” (2.sınıf öğrencisi)

Sık görülen hastalıklar derslerine ilişkin görüşler değerlendirildiğinde, "Derslerin amaç ve öğrenim hedefleri belirtilmiştir." ifadesine öğrencilerin \% 34,9'unun katıldığ1; "Derslerin içeriği derslerin başlıkları ile uyumludur." ifadesine öğrencilerin \% 43,4'ünün katıldı̆̆ı; "Dersler, sorumlu öğretim üyeleri tarafından yürütülmektedir." ifadesine öğrencilerin \% 49,0'ının katıldığı; “Derslerin uygulayıcısı öğretim üyeleri amaç ve öğrenim hedefleri doğrultusunda motivedir." ifadesine öğrencilerin \% 33,9'unun katıldı̆̆ 1 ; “Dersler aksatılmaksızın belirlenen gün ve yerde işlenmektedir." ifadesine öğrencilerin \% 40,5'inin katıldı̆̆ 1 ; "Ders öncesinde öğrencilerin dersle ilgili beklentileri öğrenilmektedir.” ifadesine öğrencilerin \% 32,1'inin katılmadığı; "Derslere devam zorunluluğu olduğu için katıliyorum." ifadesine öğrencilerin \% 37,7'sinin katıldı̆̆ı; "Derslerin Hekimlik mesleğine katkısı olacağını düşünüyorum." ifadesine öğrencilerin \% 33,0’’nın katıldığ 1 saptanmıştır (Tablo 5).

Öğrencilerin S1k görülen Hastalıklar derslerine ilişkin geribildirimleri "Öğrenme süreci”,
"Derslerin içeriğì", "Ders Programı" olmak üzere üç tema olarak analiz edilmiştir.

Örnek geribildirimler:

"İlk sınıftan hastalıklarla tanışmanın çok işimize yarayacağını düşünüyorum.” (1.sınıf öğrencisi)

"Bence bu dersler hekimlik açısından çok faydalı.” (1.sınıf öğrencisi)

"Sık görüldüğü için ilerleyen hayatımda kullanacağımı, en azından bilmem gerektiğini düşünüyorum.” (2.sınıf öğrencisi)

"Mesleğimizle alakalı olduğu için işlenmesinde bir sorun görmüyorum ama yine konular çok alakasız." (1.sınıf öğrencisi)

Öğrencilerin Sık görülen Hastalıklar derslerine ilişkin önerileri ile ilgili örnek geribildirimler:

"Klinik bilgiler ilgimi çekiyor. Daha çok yer verilmeli.” (1.sınıf öğrencisi)

“Ders sayısı arttırılabilir.” (1.sınıf öğrencisi)

\section{Tartışma}

Araştırmamızda öğrenciler, insan bilimleri, etik ile ilgili dersler hakkında olumlu görüşler bildirmişlerdir. Pamukkale Üniversitesi Tıp Fakültesi öğrencileri ile yapılmış bir araştırmada da benzer bulgular elde edilmiştir. Pamukkale Üniversitesi Tıp Fakültesi'nde 2010-2011 Eğitim-öğretim yılından itibaren uygulanmakta olan "Tipta İnsan Bilimleri Eğitim Programı”'nın 4. Yılında programın değerlendirmesini yapmak, iyi işleyen faktörleri belirlemek, eksik yönleri görmek ve öğrencilerin önerilerini almak amacı ile Dönem I ve Dönem 2 öğrencilerine $(n=170)$ yapılan anket çalışması sonucunda iki sınıf arasında anlamlı bir fark bulunamamıştır $(p>0.05)$. Pamukkale Üniversitesi Tıp Fakültesi Tıpta İnsan Bilimleri programı hedefleri arasında olan "entelektüel bakış açısını genişletme" ve "kişisel gelişime katkı" cevabı en yüksek ortalamaları almıştır 
(15). Benzer şekilde araştırmamızda insan bilimleri, sosyal tıp, etik derslerine ilişkin görüşler değerlendirildiğinde insan bilimleri, sosyal tıp ve etik ile ilgili konular hakkında bilgi edinmenin hekimlik açısından önemli olduğu belirtilmiştir. İtalya ve İngiltere'de farklı araştırmacılar tarafından tıp öğrencileri ile yapılmış çalışmalarda da benzer şekilde öğrencilerin tıbbi etik alanında eğitimi gerekli buldukları saptanmıştır $(16,17)$. Derinlemesine bireysel görüşmelerin yapıldığı bir başka araştırmada da tıp öğrencileri insan bilimleri ile ilgili dersler hakkında çok olumlu görüşleri olduğunu belirtmiştir (18). Tıp eğitimlerinin başlangıcında olan hekim adaylarının, tıbbi etik alanına ilişkin algılarının ve eğitime yönelik beklentilerinin değerlendirilmesi amacı ile yapılmış bir çalışmanın sonucunda öğrencilerin \%90.0'nın tıp eğitimi kapsamında tıbbi etik eğitiminin gerekli olduğunu belirtmişlerdir (8).

Günümüzde iletişim becerileri ile ilgili derslerin tıp eğitimi programlarının ayrılmaz bir parçası olduğu görüşünde birleşilmektedir. İletişim becerileri eğitimi pek çok ülkede, klinik öncesi yıllardan başlayarak, klinik eğitim sürecinde devam edecek şekilde planlanmaktadır. Araştırmalar, tedaviye uyum, hastanın tedaviye aktif olarak katılımı ve başarılı sağlık sonuçlarına ulaşmak için sağlık hizmeti veren kişinin empati becerisini, profesyonel-hasta etkileşiminde anahtar unsur olarak tanımlamaktadir. Doktorların kötü haber vermek, ilaç kullanmaya karşı direnç gelişimiyle baş edebilmek, etik sorunları barındıran özel durumları hasta ve hasta yakınlarıyla paylaşmak, sorunlu hastayla uğraşmak, ölümcül hastalar ve yakınlarıyla tanı sürecini paylaşmak gibi zor durumlarda hekimlik uygulamaları için eğitimleri süresince hazırlanmaya gereksinim duydukları kabul edilmektedir. İletişim becerileri eğitimi ile ilgili olarak Marmara Üniversitesi T1p Fakültesi öğrencileri ile yapılmış bir araştırmada öğrencilerin yaklaşık üçte ikisi (\%74.7) programın amaçlarına ulaştığını, \% 71.8'i programın tıp eğitimiyle bağlantısı olduğunu, \% 71.8 'i programın organizasyonunu beğendiğini, \% 82.9'u soru sorma ve eğitmenlerle etkileşime girme olanağı açısından programın mükemmel veya iyi olduğunu bildirmiştir. Öğrenciler programın kişisel beklentileri karşılama (\% 64.8) ve eğitim araç-gereçleri açısından daha az oranda yeterli olduğunu (\% 50.7) düşünmektedir (19).

Ankara Üniversitesi Tıp Fakültesinde de öğrenciler, temel bilgisayar kullanım becerileri ile KDT programında tanışmaktadır. KDT eğitimi yapan Hacettepe Üniversitesi Tip Fakültesinde 1. sinıftan 3. sinıfa kadar öğrenciler "İyi Hekimlik Uygulamaları" programı içerisinde yer alan "tıpta karar verme" kulvarında, sırasıyla bilgi okuryazarlığı, karar verme teknikleri kanıta dayalı tıp derslerini almaktadır. Dönem 4'te özellikle genel cerrahi, dahiliye ve pediyatri stajlarında öğrencilerin kanıta dayalı tıp oturumları bulunmaktadır (20).

\section{Sonuç}

Önümüzdeki eğitim-öğretim yıllarında, öğrenci geri bildirimleri ile birlikte öğretim üyelerinden geri bildirim alınarak dikey koridor programı kapsamındaki derslerin geliştirilmesi planlanmaktadır. $\mathrm{Bu}$ sonuçlarla Trakya Üniversitesi Tıp Fakültesi'nde uygulanan dikey koridor Programı, tıp fakültesi öğrencilerinin geniş birperspektifbakışaçısıile düşünebilmesini sağlayan, kişisel gelişimine katkıda bulunan ve meslek yaşamına hazırlanmada katkısı olan bir program olarak değerlendirilebilir. Programın bu değerlendirmelerle daha iyi bir düzeye getirilebileceği düşünülmektedir. 
1. Mezuniyet Öncesi Tıp Eğitimi Ulusal Çekirdek Eğitim Programı, 2014.

2. TEPDAD Mezuniyet Öncesi Tıp Eğitimi Ulusal Standartları, 2018, Çevrimiçi: http:// tepdad.org.tr/uploads/files/Belgeler $\% 20$ ve\%20formlar/5word-MOTE\%202018\%20 STANDARTLARI.pdf , Erişim tarihi: 12.01.2019.

3. Uğurlu A.N, Toplumun İhtiyaçları Tıp Eğitiminin Yeniden Yapılandırılmasını Gerektiriyor mu?. Ankara Medical Journal, 2012, 12(2):95-99.

4. Turan S, Sincan M, Elçin M, Odabaşı O, Sayek İ. Tıp Fakültelerinde Klinik Öncesi Dönemde Araştırma Eğitimi. Tıp Eğitimi Dünyas1, Ekim 2007, Say1 26.

5. Isaac M, Rief W. Role of Behavioural and Social Sciences in Medical Education. Current Opinion in Psychiatry 2009, 22:184-187.

6. Ousager J, Johannessen H. Humanities in Undergraduate Medical Education: A Literature Review. Academic Medicine, 85:988-998, No.6 / June 2010.

7. Doukas D.J., Mc Cullough L.B., Wear S. Medical Education in Medical Ethics and Humanities as the Foundation for Developing Medical Professionalism. Acad Med. 2012; 87:334-341.

8. Timbil, S, Özan S, Şemin S, Musal B. Tıp Fakültesine Yeni Başlayan Öğrencilerin Tıbbi Etik Konularına ve Eğitimine İlişkin Değerlendirmeleri, Tıp Eğitimi Dünyası Dergisi,
9. Başer A, Şahin H. Tıbbi Beşeri Bilimler, Tıp Eğitimi Dünyası / Mayıs-Ağustos 2017 / Sayı 4952.

10. Montgomery K, Chambers T, Reifler D R. Humanities Education at Northwestern University's Feinberg School of Medicine. Acad Med 2003;78:958-962.

11. Gülpinar MA, Akman M, User I. A Course, 'The Human in Medicine', as an Example of a Preclinical Medical Humanities Program: A Summary of 7 Years. Med Teach 2009;31:469476.

12. Çevrimiçi: https://tip.trakya.edu.tr Erişim tarihi: 10.01.2019.

13. Sarıkaya Ö, Gülpınar M.A, Keklik D, Kalaça S. Öğrencilerin Sesini Dinlemek: Eğitimin Öğrenciler Tarafından Değerlendirilmesi. Tıp Eğitimi Dünyası Sayı: 9 Ekim 2002.

14. Karabilgin Ö.S, Şahin H. Eğitim Etkinliğini Değerlendirmede Öğrenci Geri Bildiriminin Kullanımı. Tıp Eğitimi Dünyası Dergisi, 2012.

15. Akdoğan I, Özdel O, Akdoğan D, Topal K. Pamukkale Üniversitesi Tıp Fakültesi Tıpta İnsan Bilimleri Programının Dönem 1 ve Dönem 2 Öğrencileri Tarafından Değerlendirilmesi. Pamukkale T1p Dergisi, 2016; 9(1):39-44.

16. Piccoli GB, Mezza E, Soragna G, Burdese M, Bermond F, Grassi G, Jeantet A, Segoloni GP. What Do Italian Medical Students Read? A Call For a Library of Good Books on Physicians for Physicians. Journal of Medical Ethics: Medical Humanities 2003; 29: 54-56. 
17. Johnston C, Haughton P. Medical Students' Perceptions of Their Ethics Teaching. Journal of Medical Ethics 2007; 33: 418-422.

18. Wachtler C, Lundin S, Troein M. Humanities for Medical Students? A Gualitative Study of a Medical Humanities Curriculum in a Medical School Program. BMC Medical Education 2006, 6:16.

19. Sarıkaya Ö, Uzuner A, Gülpınar M.A, Keklik D, Kalaça S. İletişim Becerileri Eğitimi: İçerik ve Değerlendirme. Tıp Eğitimi Dünyası, Say1:14, Ocak 2004.

20. İlhan M.N., Maral I, Güney Z, Haznedaroğlu Ş, Çakır N, Tunaoğlu F.S, Sözen S, Dursun A. Gazi Üniversitesi Tıp Fakültesinde Kanıta Dayalı Tıp Eğitimi: İlk Y1l Deneyimi. Tıp Eğitimi Dünyası Ocak 2007 Sayı 24. 
Tablo 1: Bilim Okuryazarhĕ̉ Dcrsi ile ilgili görūșlerin saklık dağılımlan

\begin{tabular}{|c|c|c|c|c|c|c|}
\hline $\begin{array}{l}\text { Bulim Okuryazarhg! } \\
\text { Dersi lle Ilgili }\end{array}$ & 曾 & 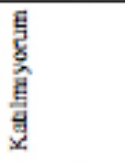 & 具 & 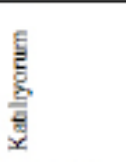 & 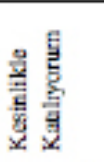 & 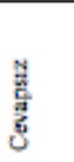 \\
\hline Gôruster & $\mathrm{n}(\%)$ & $\mathrm{n}(\%)$ & $\mathbf{n}(\%)$ & $n(\%)$ & $n(\%)$ & $\mathrm{n}(\%)$ \\
\hline $\begin{array}{l}\text { Dersin amę ve } \\
\text { oğrenim hedefleri } \\
\text { belirtilmiştir. }\end{array}$ & $35(19,1)$ & $34(18,6)$ & $41(22,4)$ & $\begin{array}{c}53 \\
(29,0)\end{array}$ & $\begin{array}{c}19 \\
(10,4)\end{array}$ & $\begin{array}{c}1 \\
(0,5)\end{array}$ \\
\hline $\begin{array}{l}\text { Dersin yapelace ğ1 ycr } \\
\text { belirlidir. }\end{array}$ & $12(6,6)$ & $19(10,4)$ & $15(8,2)$ & $69(37,7)$ & $\begin{array}{c}68 \\
(37,2)\end{array}$ & - \\
\hline $\begin{array}{l}\text { Ders, sorumlu } \\
\text { öjretim üycsi } \\
\text { tarafinden } \\
\text { yürutulmektedir. }\end{array}$ & $9(4,9)$ & $10(5,5)$ & $21(11,5)$ & $87(47,5)$ & $\begin{array}{c}56 \\
(30,6)\end{array}$ & - \\
\hline $\begin{array}{l}\text { Dersin wyzulaycısı } \\
\text { ogectim üycsi amạ } \\
\text { ve ögrenim hodefleri } \\
\text { doğrultusunda } \\
\text { motivodir. }\end{array}$ & $20(10,9)$ & $40(21,9)$ & $33(18,0)$ & $\begin{array}{c}63 \\
(34,4)\end{array}$ & $\begin{array}{c}26 \\
(142)\end{array}$ & $\begin{array}{c}1 \\
(0.5)\end{array}$ \\
\hline $\begin{array}{l}\text { Dersler } \\
\text { aksatilmaksızın } \\
\text { belirlencn gun we } \\
\text { yerde iłlenmektedir. }\end{array}$ & $23(12,6)$ & $29(15,8)$ & $21(11,5)$ & $70(38,3)$ & $\begin{array}{c}38 \\
(20,8)\end{array}$ & $\begin{array}{c}2 \\
(1,1)\end{array}$ \\
\hline $\begin{array}{l}\text { Ders ôncesindo } \\
\text { ogrencilerin derslo } \\
\text { ilgaili bekjentileri } \\
\text { og̣renilmektedir. }\end{array}$ & $53(29.0)$ & $52(28,4)$ & $37(20.2)$ & $\begin{array}{c}26 \\
(14,2)\end{array}$ & $15(8,2)$ & - \\
\hline $\begin{array}{l}\text { Ders içeriģi ve alıı̧ı } \\
\text { sınıfumızda hee grup } \\
\text { için benzer pekildodir. }\end{array}$ & $48(26.2)$ & $33(18,0)$ & $46(25,1)$ & $40(21,9)$ & $16(8,7)$ & - \\
\hline $\begin{array}{l}\text { Ders programinin } \\
\text { zmman kurgusu } \\
\text { uygun, derslex aras } \\
\text { süre yeterli. }\end{array}$ & $42(23,0)$ & $27(14,8)$ & $35(19,1)$ & $59(32,2)$ & $17(9,3)$ & $\begin{array}{c}3 \\
(1,6)\end{array}$ \\
\hline $\begin{array}{l}\text { Dersten sorumlu } \\
\text { ogretim dycsiyle } \\
\text { birlikte derste } \\
\text { oğrendiklerimizi } \\
\text { uygulamzk amacayla } \\
\text { bir arastirma yzprnayn } \\
\text { planladik. }\end{array}$ & $74(40,4)$ & $45(24,6)$ & $18(9,8)$ & $\begin{array}{c}33 \\
(18,0)\end{array}$ & $13(7,1)$ & - \\
\hline 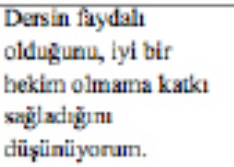 & $55(30,1)$ & $34(18,6)$ & $42(23,0)$ & $40(21,9)$ & $12(6,6)$ & $\overline{7}$ \\
\hline $\begin{array}{l}\text { Bilim Okuryazartı̆ } \\
\text { eğ fitimime aym hoca } \\
\text { ile devam etmek } \\
\text { isterim. }\end{array}$ & 31 $(16,9)$ & $15(8,2)$ & $35(19,1)$ & $48(26,2)$ & $\begin{array}{c}54 \\
(29,5)\end{array}$ & $\cdot$ \\
\hline
\end{tabular}


Tablo 2: Hastane Gezileri ile ilgili görüșlerin sıklık dağılımları

\begin{tabular}{|c|c|c|c|c|c|c|}
\hline $\begin{array}{l}\text { Hastane Gezileri İle İlgili } \\
\text { Görüșler }\end{array}$ & 嵒总 & $\begin{array}{l}\text { 㤩 } \\
\text { 窟 } \\
\text { 总 }\end{array}$ & 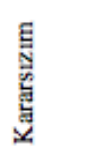 & 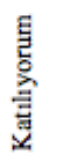 & 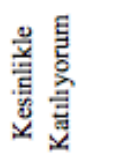 & ปै. \\
\hline & $\mathrm{n}(\%)$ & $\mathrm{n}(\%)$ & $\mathrm{n}(\%)$ & $\mathrm{n}(\%)$ & $\mathrm{n}(\%)$ & $\mathrm{n}(\%)$ \\
\hline $\begin{array}{l}\text { Gezi sırasında gittiğim bölümde } \\
\text { bilgilendirilmiş bir gōrevliyle } \\
\text { gōrüşebildim. }\end{array}$ & $\begin{array}{c}11 \\
(16,2)\end{array}$ & $\begin{array}{c}13 \\
(19,1)\end{array}$ & $\begin{array}{c}17 \\
(25,0)\end{array}$ & $\begin{array}{c}22 \\
(32,4)\end{array}$ & $4(5,9)$ & $1(1,5)$ \\
\hline $\begin{array}{l}\text { Gezide karşllayan görevlinin } \\
\text { faydalı olduğunu düşünüyorum. }\end{array}$ & $\begin{array}{c}5 \\
(7,4)\end{array}$ & $\begin{array}{c}13 \\
(19,1)\end{array}$ & $\begin{array}{c}23 \\
(33,8)\end{array}$ & $\begin{array}{c}19 \\
(27,9)\end{array}$ & $7(10,3)$ & $1(1,5)$ \\
\hline $\begin{array}{l}\text { Gezinin planlandığı anabilim } \\
\text { dalının ya da kliniğin yerini } \\
\text { bulmakta güçlük çekiyorum. }\end{array}$ & $\begin{array}{c}4 \\
(5,9)\end{array}$ & $\begin{array}{c}15 \\
(22,1)\end{array}$ & $5(7,4)$ & $\begin{array}{c}27 \\
(39,7)\end{array}$ & $\begin{array}{c}16 \\
(23,5)\end{array}$ & $1(1,5)$ \\
\hline $\begin{array}{l}\text { Gezileri çalışan katkısı olmaksızın } \\
\text { tamamladım. }\end{array}$ & $\begin{array}{c}4 \\
(5,9)\end{array}$ & $\begin{array}{c}26 \\
(38,2)\end{array}$ & $\begin{array}{c}15 \\
(22,1)\end{array}$ & $\begin{array}{c}18 \\
(26,5)\end{array}$ & $3(4,4)$ & $2(2,9)$ \\
\hline $\begin{array}{l}\text { Geziler sayesinde hastaneyi tanıdım } \\
\text { ve neler yapıldığını ögrendim. }\end{array}$ & $\begin{array}{c}3 \\
(4,4)\end{array}$ & $\begin{array}{c}8 \\
(11,8)\end{array}$ & $\begin{array}{c}13 \\
(19,1)\end{array}$ & $\begin{array}{c}34 \\
(50,0)\end{array}$ & $\begin{array}{c}9 \\
(13,2)\end{array}$ & $\begin{array}{c}1 \\
(1,5)\end{array}$ \\
\hline $\begin{array}{l}\text { Gezilerin faydalı olduğunu } \\
\text { düşünüyorum. }\end{array}$ & $\begin{array}{c}8 \\
(11,8)\end{array}$ & $\begin{array}{c}5 \\
(7,4)\end{array}$ & $\begin{array}{c}13 \\
(19,1)\end{array}$ & $\begin{array}{c}29 \\
(42,6)\end{array}$ & $\begin{array}{c}12 \\
(17,6)\end{array}$ & $\begin{array}{c}1 \\
(1,5)\end{array}$ \\
\hline
\end{tabular}

Tablo 3: İnsan Bilimleri, Sosyal Tıp, Etik, Girişimcilik Dersleri ile ilgili görüşlerin sıklık dağılımları

\begin{tabular}{|c|c|c|c|c|c|c|}
\hline $\begin{array}{l}\text { İnsan Bilimleri, Sosyal Tip, Etik } \\
\text { Girişimcilik Dersleri İle İlgili } \\
\text { Görüşler }\end{array}$ & 总 & 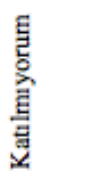 & 㤩 & 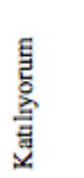 & 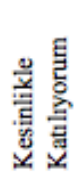 & 卷 \\
\hline & $\mathrm{n}(\%)$ & $\mathrm{n}(\%)$ & $\mathrm{n}(\%)$ & $\mathrm{n}(\%)$ & $\mathrm{n}(\%)$ & $\mathrm{n}(\%)$ \\
\hline $\begin{array}{l}\text { Ders konularını çok ilginç } \\
\text { buluyorum ve içeriğini merak } \\
\text { ediyorum. }\end{array}$ & $36(19,7)$ & $\begin{array}{c}29 \\
(15,8)\end{array}$ & $\begin{array}{c}34 \\
(18,6)\end{array}$ & $\begin{array}{c}23 \\
(12,6)\end{array}$ & $\begin{array}{c}7 \\
(3,8)\end{array}$ & $\begin{array}{c}54 \\
(29,5)\end{array}$ \\
\hline $\begin{array}{l}\text { Bu derslerin iyi hekimlik } \\
\text { değerlerini edinmeme katkısı } \\
\text { olacağını düşünüyorum. }\end{array}$ & $32(17,5)$ & $\begin{array}{c}19 \\
(10,4)\end{array}$ & $\begin{array}{c}35 \\
(19,1)\end{array}$ & $\begin{array}{c}35 \\
(19,1)\end{array}$ & $\begin{array}{c}8 \\
(4,4)\end{array}$ & $\begin{array}{c}54 \\
(29,5)\end{array}$ \\
\hline $\begin{array}{l}\text { Derslere devam zorunluluğu } \\
\text { olduğu için katilyyorum. }\end{array}$ & $\begin{array}{c}4 \\
(2,2)\end{array}$ & $\begin{array}{c}8 \\
(4,4)\end{array}$ & $\begin{array}{c}14 \\
(7,7)\end{array}$ & $\begin{array}{c}37 \\
(20,2)\end{array}$ & $\begin{array}{c}66 \\
(36,1)\end{array}$ & $\begin{array}{c}54 \\
(29,5)\end{array}$ \\
\hline $\begin{array}{l}\text { Derslere tup derslerine çalışmam } \\
\text { gerektiği için katılmıyorum. }\end{array}$ & $\begin{array}{c}18 \\
(9,8)\end{array}$ & $\begin{array}{c}17 \\
(9,3)\end{array}$ & $\begin{array}{c}26 \\
(14,2)\end{array}$ & $\begin{array}{c}39 \\
(21,3)\end{array}$ & $\begin{array}{c}26 \\
(14,2)\end{array}$ & $\begin{array}{c}57 \\
(31,1)\end{array}$ \\
\hline $\begin{array}{l}\text { Dersleri ilgi çekici bulduğum için } \\
\text { katıllyorum. }\end{array}$ & $\begin{array}{c}44 \\
(24,0)\end{array}$ & $\begin{array}{c}24 \\
(13,1)\end{array}$ & $\begin{array}{c}32 \\
(17,5)\end{array}$ & $\begin{array}{c}21 \\
(11,5)\end{array}$ & $\begin{array}{c}6 \\
(3,3)\end{array}$ & $\begin{array}{c}56 \\
(30,6)\end{array}$ \\
\hline $\begin{array}{l}\text { Derslere kurul sınavında ilgili soru } \\
\text { sorulmadığı için katılmıorum. }\end{array}$ & $39(21,3)$ & $\begin{array}{c}33 \\
(18,0)\end{array}$ & $\begin{array}{c}26 \\
(14,2)\end{array}$ & $\begin{array}{c}22 \\
(12,0)\end{array}$ & $\begin{array}{c}9 \\
(4,9)\end{array}$ & $\begin{array}{c}54 \\
(29,5)\end{array}$ \\
\hline $\begin{array}{l}\text { Kurul sınavında bu derslerle ilgili } \\
\text { soru sorulsaydı derslere katılırdım. }\end{array}$ & $49(26,8)$ & $\begin{array}{c}28 \\
(15,3)\end{array}$ & $\begin{array}{c}24 \\
(13,1)\end{array}$ & $\begin{array}{c}16 \\
(8,7)\end{array}$ & $\begin{array}{c}11 \\
(6,0)\end{array}$ & $\begin{array}{c}55 \\
(30,1)\end{array}$ \\
\hline
\end{tabular}


Tablo 4: Tematik Konferanslar ile ilgili görüşlerin sıklık dağılımları

\begin{tabular}{|c|c|c|c|c|c|c|}
\hline $\begin{array}{l}\text { Tematik Konferanslar İle İlgili } \\
\text { Görüşler }\end{array}$ & 造总 & 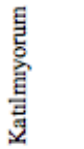 & 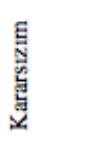 & 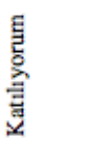 & 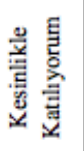 & 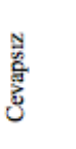 \\
\hline & $\mathrm{n}(\%)$ & n (\%) & n (\%) & $\mathrm{n}(\%)$ & $\mathrm{n}(\%)$ & $\mathrm{n}(\%)$ \\
\hline $\begin{array}{l}\text { Konuları çok ilginç buluyorum ve } \\
\text { içeriğini merak ediyorum. }\end{array}$ & $\begin{array}{c}45 \\
(24,6)\end{array}$ & $\begin{array}{c}31 \\
(16,9)\end{array}$ & $\begin{array}{c}46 \\
(25,1)\end{array}$ & $\begin{array}{c}26 \\
(14,2)\end{array}$ & $7(3,8)$ & $\begin{array}{c}28 \\
(15,3)\end{array}$ \\
\hline $\begin{array}{l}\text { Tematik Konferansların amaç ve } \\
\text { ögrrenim hedefleri belirlidir. }\end{array}$ & $\begin{array}{c}35 \\
(19,1)\end{array}$ & $\begin{array}{c}21 \\
(11,5)\end{array}$ & $\begin{array}{c}39 \\
(21,3)\end{array}$ & $\begin{array}{c}49 \\
(26,8)\end{array}$ & $9(4,9)$ & $\begin{array}{c}30 \\
(16,4)\end{array}$ \\
\hline $\begin{array}{l}\text { Konferansların iyi hekimlik } \\
\text { değerlerini edinmeme katkısı } \\
\text { olacağını düşünüyorum. }\end{array}$ & $39(21,3)$ & $\begin{array}{c}22 \\
(12,0)\end{array}$ & $\begin{array}{c}40 \\
(21,9)\end{array}$ & $\begin{array}{c}43 \\
(23,5)\end{array}$ & $\begin{array}{c}10 \\
(5,5)\end{array}$ & $\begin{array}{c}29 \\
(15,8)\end{array}$ \\
\hline $\begin{array}{l}\text { Konferanslara ilgi çekici bulduğum } \\
\text { için katılıyorum. }\end{array}$ & $50(27,3)$ & $\begin{array}{c}35 \\
(19,1)\end{array}$ & $\begin{array}{c}34 \\
(18,6)\end{array}$ & $\begin{array}{c}29 \\
(15,8)\end{array}$ & $\begin{array}{c}7 \\
(3,8)\end{array}$ & $\begin{array}{c}28 \\
(15,3)\end{array}$ \\
\hline $\begin{array}{l}\text { Konferanslara tıp derslerine } \\
\text { çalışmam gerektiği için } \\
\text { katılmıyorum. }\end{array}$ & $18(9,8)$ & $\begin{array}{c}28 \\
(15,3)\end{array}$ & $\begin{array}{c}31 \\
(16,9)\end{array}$ & $\begin{array}{c}44 \\
(24,0)\end{array}$ & $\begin{array}{c}34 \\
(18,6)\end{array}$ & $\begin{array}{c}28 \\
(15,3)\end{array}$ \\
\hline $\begin{array}{l}\text { Konferanslara devam zorunluluğu } \\
\text { olduğu için katılyyorum. }\end{array}$ & $11(6,0)$ & $\begin{array}{c}10 \\
(5,5)\end{array}$ & $\begin{array}{c}24 \\
(13,1)\end{array}$ & $\begin{array}{c}52 \\
(28,4)\end{array}$ & $\begin{array}{c}58 \\
(31,7)\end{array}$ & $\begin{array}{c}28 \\
(15,3)\end{array}$ \\
\hline
\end{tabular}

Tablo 5: Sık görülen Hastahılar Dersleri ile ilgili görüşlerin sıklık dağılımları

\begin{tabular}{|c|c|c|c|c|c|c|}
\hline $\begin{array}{l}\text { Sık Görülen Hastalıklar Dersleri f́le } \\
\text { İlgili Görüşler }\end{array}$ & 总总 & 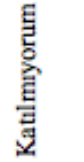 & 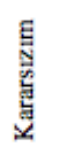 & 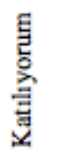 & 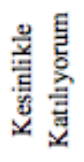 & 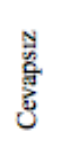 \\
\hline & $\mathrm{n}(\%)$ & $\mathrm{n}(\%)$ & $\mathrm{n}(\%)$ & $\mathrm{n}(\%)$ & $\mathrm{n}(\%)$ & $\mathrm{n}(\%)$ \\
\hline $\begin{array}{l}\text { Derslerin amaç ve öğrenim hedefleri } \\
\text { belirtilmiștir. }\end{array}$ & $\begin{array}{c}3 \\
(2,8)\end{array}$ & $\begin{array}{c}6 \\
(5,7)\end{array}$ & $\begin{array}{c}19 \\
(17,9)\end{array}$ & $\begin{array}{c}25 \\
(23,6)\end{array}$ & $\begin{array}{c}12 \\
(11,3)\end{array}$ & $\begin{array}{c}41 \\
(38,7)\end{array}$ \\
\hline $\begin{array}{l}\text { Derslerin içeriği derslerin başlıkları ile } \\
\text { uyumludur. }\end{array}$ & $\begin{array}{c}2 \\
(1,9)\end{array}$ & $\begin{array}{c}2 \\
(1,9)\end{array}$ & $\begin{array}{c}15 \\
(14,2)\end{array}$ & $\begin{array}{c}33 \\
(31,1)\end{array}$ & $\begin{array}{c}13 \\
(12,3)\end{array}$ & $\begin{array}{c}41 \\
(38,7)\end{array}$ \\
\hline $\begin{array}{l}\text { Derslerin yapılacağı tarih ve yer } \\
\text { belirlidir. }\end{array}$ & $\begin{array}{c}2 \\
(1,9)\end{array}$ & $\begin{array}{c}1 \\
(0,9)\end{array}$ & $\begin{array}{c}11 \\
(10,4)\end{array}$ & $\begin{array}{c}36 \\
(34,0)\end{array}$ & $\begin{array}{c}15 \\
(14,2)\end{array}$ & $\begin{array}{c}41 \\
(38,7)\end{array}$ \\
\hline $\begin{array}{l}\text { Dersler, sorumlu ög̈retim üyeleri } \\
\text { tarafından yürütülmektedir. }\end{array}$ & $\begin{array}{c}2 \\
(1,9)\end{array}$ & - & $\begin{array}{c}10 \\
(9,4)\end{array}$ & $\begin{array}{c}38 \\
(35,8)\end{array}$ & $\begin{array}{c}14 \\
(13,2)\end{array}$ & $\begin{array}{c}42 \\
(39,6)\end{array}$ \\
\hline $\begin{array}{l}\text { Derslerin uygulayıcısı öğretim üyeleri } \\
\text { amaç ve öğrenim hedefleri } \\
\text { doğrultusunda motivedir. }\end{array}$ & $\begin{array}{c}5 \\
(4,7)\end{array}$ & $\begin{array}{c}5 \\
(4,7)\end{array}$ & $\begin{array}{c}18 \\
(17,0)\end{array}$ & $\begin{array}{c}26 \\
(24,5)\end{array}$ & $\begin{array}{c}10 \\
(9,4)\end{array}$ & $\begin{array}{c}42 \\
(39,6)\end{array}$ \\
\hline $\begin{array}{l}\text { Dersler aksatılmaksızın belirlenen gün ve } \\
\text { yerde işlenmektedir. }\end{array}$ & $\begin{array}{c}6 \\
(5,7)\end{array}$ & $\begin{array}{c}6 \\
(5,7)\end{array}$ & $9(8,5)$ & $\begin{array}{c}31 \\
(29,2)\end{array}$ & $\begin{array}{c}12 \\
(11,3)\end{array}$ & $\begin{array}{c}42 \\
(39,6)\end{array}$ \\
\hline $\begin{array}{l}\text { Ders öncesinde öğrencilerin dersle ilgili } \\
\text { beklentileri öğrenilmektedir. }\end{array}$ & $\begin{array}{c}19 \\
(17,9)\end{array}$ & $\begin{array}{c}15 \\
(14,2)\end{array}$ & $\begin{array}{c}15 \\
(14,2)\end{array}$ & $\begin{array}{c}12 \\
(11,3)\end{array}$ & $4(3,8)$ & $\begin{array}{c}41 \\
(38,7)\end{array}$ \\
\hline $\begin{array}{l}\text { Dersleri ilgi çekici bulduğum için } \\
\text { katıllyorum. }\end{array}$ & $\begin{array}{c}15 \\
(14,2)\end{array}$ & $\begin{array}{c}8 \\
(7,5)\end{array}$ & $\begin{array}{c}19 \\
(17,9)\end{array}$ & $\begin{array}{c}19 \\
(17,9)\end{array}$ & $\begin{array}{c}3 \\
(2,8)\end{array}$ & $\begin{array}{c}42 \\
(39,6)\end{array}$ \\
\hline $\begin{array}{l}\text { Derslere devam zorunluluğu olduğu için } \\
\text { katılıyorum. }\end{array}$ & $\begin{array}{c}8 \\
(7,5)\end{array}$ & $\begin{array}{c}5 \\
(4,7)\end{array}$ & $\begin{array}{c}12 \\
(11,3)\end{array}$ & $\begin{array}{c}17 \\
(16,0)\end{array}$ & $\begin{array}{c}23 \\
(21,7)\end{array}$ & $\begin{array}{c}41 \\
(38,7)\end{array}$ \\
\hline $\begin{array}{l}\begin{array}{l}\text { Derslerin Hekimlik mesleğine katkısı } \\
\text { olacağını düşünüyorum. }\end{array} \\
\end{array}$ & $\begin{array}{c}8 \\
(7,5) \\
\end{array}$ & $\begin{array}{c}3 \\
(2,8)\end{array}$ & $\begin{array}{c}18 \\
(17,0) \\
\end{array}$ & $\begin{array}{c}25 \\
(23,6) \\
\end{array}$ & $\begin{array}{c}10 \\
(9,4)\end{array}$ & $\begin{array}{c}42 \\
(39,6) \\
\end{array}$ \\
\hline
\end{tabular}

